\title{
Modulation of the cardiac sodium/bicarbonate cotransporter by the renin angiotensin aldosterone system: pathophysiological consequences
}

\author{
Verónica C. De Giusti, María C. Ciancio, Alejandro Orlowski and Ernesto A. Aiello* \\ Facultad de Ciencias Médicas, Centro de Investigaciones Cardiovasculares, Universidad Nacional de La Plata, CONICET-La Plata, La Plata, Argentina
}

Edited by:

Ebbe Boedtkjer, Aarhus University,

Denmark

Reviewed by:

Alessandro Sardini, Imperial College London, UK

Carolina D. Garciarena, University of

Oxford, UK

\section{*Correspondence:}

Ernesto A. Aiello, Facultad de Ciencias Médicas, Centro de

Investigaciones Cardiovasculares, Universidad Nacional de La Plata, Calle 60 y 120, 1900 La Plata, Argentina

e-mail: aaiello@med.un/p.edu.ar
The sodium/bicarbonate cotransporter (NBC) is one of the major alkalinizing mechanisms in the cardiomyocytes. It has been demonstrated the existence of at least two functional isoforms, one that promotes the co-influx of 1 molecule of $\mathrm{Na}^{+}$per 1 molecule of $\mathrm{HCO}_{3}^{-}$(electroneutral isoform; NBCn1) and the other one that generates the co-influx of 1 molecule of $\mathrm{Na}^{+}$per 2 molecules of $\mathrm{HCO}_{3}^{-}$(electrogenic isoform; NBCe1). Both isoforms are important to maintain intracellular $\mathrm{pH}\left(\mathrm{pH}_{i}\right)$ and sodium concentration $\left(\left[\mathrm{Na}^{+}\right]_{i}\right)$. In addition, NBCe1 generates an anionic repolarizing current that modulates the action potential duration (APD). The renin-angiotensin-aldosterone system (RAAS) is implicated in the modulation of almost all physiological cardiac functions and is also involved in the development and progression of cardiac diseases. It was reported that angiotensin II (Ang II) exhibits an opposite effect on NBC isoforms: it activates NBCn1 and inhibits NBCe1. The activation of NBCn1 leads to an increase in $\mathrm{pH}_{i}$ and $\left[\mathrm{Na}^{+}\right]_{i}$, which indirectly, due to the stimulation of reverse mode of the $\mathrm{Na}^{+} / \mathrm{Ca}^{2+}$ exchanger (NCX), conduces to an increase in the intracellular $\mathrm{Ca}^{2+}$ concentration. On the other hand, the inhibition of NBCe1 generates an APD prolongation, potentially representing a risk of arrhythmias. In the last years, the potentially altered NBC function in pathological scenarios, as cardiac hypertrophy and ischemia-reperfusion, has raised increasing interest among investigators. This review attempts to draw the attention on the relevant regulation of NBC activity by RAAS, since it modulates $\mathrm{pH}_{i}$ and $\left[\mathrm{Na}^{+}\right]_{i}$, which are involved in the development of cardiac hypertrophy, the damage produced by ischemia-reperfusion and the generation of arrhythmic events, suggesting a potential role of NBC in cardiac diseases.

Keywords: sodium bicarbonate cotransporter, angiotensin II, aldosterone, hypertrophy, heart

\section{INTRODUCTION}

The adequate regulation of intracellular $\mathrm{pH}\left(\mathrm{pH}_{i}\right)$ is essential for the heart. Fall of $\mathrm{pH}_{i}$ usually occurs in cardiac myocytes, as during changes in heart rate (Bountra et al., 1988; Elliott et al., 1994), but also a major reduction occurs during pathological conditions, such as myocardial ischemia (Steenbergen et al., 1977; Garlick et al., 1979). Two sarcolemmal alkalinizing ion transporters mediate the acid-extrusion in order to maintain $\mathrm{pH}_{i}$ near to 7.2, either exporting $\mathrm{H}^{+}\left(\mathrm{Na}^{+} / \mathrm{H}^{+}\right.$antiporter; NHE-1), or introducing $\mathrm{HCO}_{3}^{-}$into the cell, $\left(\mathrm{Na}^{+} / \mathrm{HCO}_{3}^{-}\right.$cotransporter; NBC).

It has been described at least two functional isoforms of NBC in the heart: the electroneutral $\mathrm{NBC}, \mathrm{NBCn} 1$, which promotes the co-influx of 1 molecule of $\mathrm{Na}^{+}$per 1 molecule of $\mathrm{HCO}_{3}^{-}$, and the electrogenic NBC, NBCe1, which introduces 1 molecule of $\mathrm{Na}^{+}$ per 2 molecules of $\mathrm{HCO}_{3}^{-}$.

It has been demonstrated that the increase in the intracellular sodium concentration $\left(\left[\mathrm{Na}^{+}\right]_{i}\right)$ generated by these alkalinizing transporters promotes the $\mathrm{Na}^{+} / \mathrm{Ca}^{2+}$ exchanger to work in its reverse mode (NCXr), leading to an increase in the intracellular calcium concentration $\left(\left[\mathrm{Ca}^{2+}\right]_{i}\right)$, which is involved in the pathogenesis of several cardiac diseases as hypertrophy, the damage produced by ischemia-reperfusion and the generation of arrhythmia.

The renin-angiotensin-aldosterone system (RAAS) represents one of the main endocrine systems that regulate cardiac pathophysiology. Moreover, it is well-recognized that both angiotensin II (Ang II) and aldosterone are expressed locally in the heart, exerting their effects in a paracrine and/or autocrine manner. In this regard, it has been described that Ang II and aldosterone directly stimulate the cardiac NHE-1, which is involved in the positive inotropic response (Perez et al., 2003; Caldiz et al., 2011) and cardiac hypertrophy (Cingolani et al., 2008, 2013) produced by these hormones. In addition, in the last years it has been demonstrated that NBC activity is regulated by Ang II (Baetz et al., 2002; De Giusti et al., 2009, 2010).

In the present review the evidence about the regulation of $\mathrm{NBC}$ by RAAS and the potential importance of NBC in the development and maintenance of cardiac diseases mediated by RAAS will be discussed.

ROLE OF THE CARDIAC NBC IN $\mathrm{pH}_{i}$ AND $\left[\mathrm{Na}^{+}\right]_{i}$ REGULATION At present it is known that NBC is responsible for $40-50 \%$ of total acid extrusion in cardiac myocytes under physiological 
conditions at $\mathrm{pH}_{i}$ near resting values, when total acid extrusion is low (Lagadic-Gossmann et al., 1992; Camilion De Hurtado et al., 1995). However, it is important to recognize that, although both transporters are equally operative at $\mathrm{pH}_{i}$ close to basal (Le Prigent et al., 1997; Vaughan-Jones et al., 2006, 2009; De Giusti et al., 2009), at acidic $\mathrm{pH}_{i}$ (near to 6.8) the relative importance of NBC is only of $30 \%$ against the $70 \%$ of NHE-1 (Baetz et al., 2002; Vaughan-Jones et al., 2006; De Giusti et al., 2009).

As it has been established for the NHE-1, it has been demonstrated that $\mathrm{NBC}$ increases $\left[\mathrm{Na}^{+}\right]_{i}$ (Yamamoto et al., 2005; Vaughan-Jones et al., 2006). The increase in $\left[\mathrm{Na}^{+}\right]_{i}$ is crucial for cardiac pathophysiology because, as it is well-known, it stimulates NCXr, leading to an increase in $\left[\mathrm{Ca}^{2+}\right]_{i}$ (Rothstein et al., 2002; Bril, 2003; Perez et al., 2003; Aiello et al., 2005), process which is involved in Ang II-induced positive inotropic effects (Aiello et al., 2005) and cardiac hypertrophy (Dulce et al., 2006; Cingolani et al., 2008). In this regard, it was proposed that this phenomenon might be involved in NBC-induced cardiac diseases (Khandoudi et al., 2001; Bril, 2003; Baartscheer and Van Borren, 2008; De Giusti et al., 2010) (Figure 1).

In addition, since it was suggested that the mineralocorticoid receptors (MR) appears to be located downstream of Ang II in the chain of intracellular signals leading to the slow force response (SFR) (Caldiz et al., 2011), the activation of this receptors by aldosterone could also be implicated in the regulation of cardiac contractility. Consistently, an aldosterone-induced positive inotropic effect has been previously reported in rat myocardium (Barbato et al., 2002, 2004).

Recently, it was demonstrated that NBCe1 is homogeneously physically and functionally localized in lateral sarcolemma,

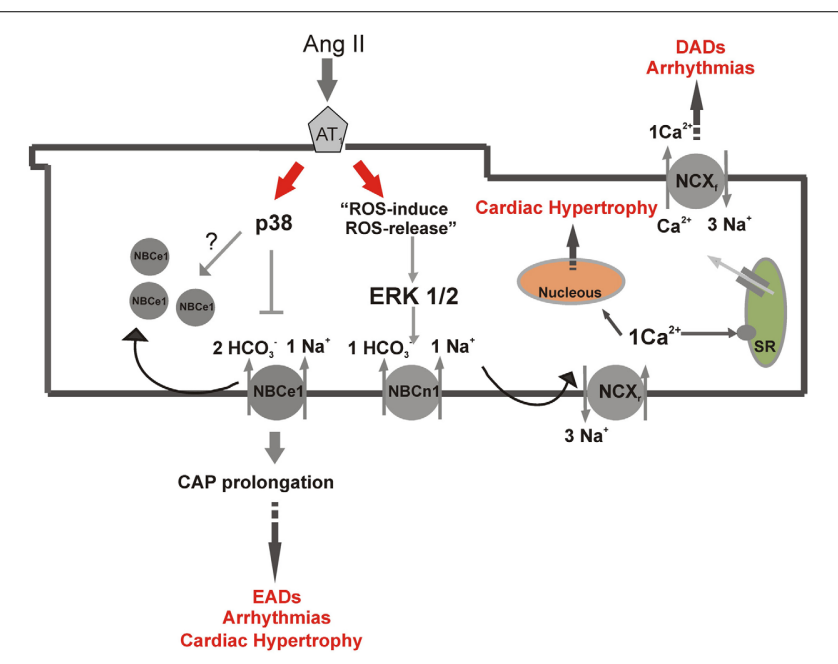

FIGURE 1 | Differential NBC isoforms regulation by angiotensin II. Scheme of parallel Ang II-pathways in a ventricular myocyte, showing $\mathrm{NBCn} 1$ stimulation and NBCe1 inhibition and the possible implications of these regulations in the development of cardiac pathologies, as hypertrophy and arrhythmias. p38, p38 kinase; ERK 1/2, ERK kinase; EADs, early after depolarizations; DADs, delay after depolarizations; SR, sarcoplasmatic reticulum; CAP, cardiac action potential; NCXr, reverse mode of sodium/calcium exchanger; NCXf, forward mode of sodium/calcium exchanger. intercalated disc and especially in the transverse tubules, colocalized with the NCX (Garciarena et al., 2013a). In contrast, NHE-1 is expressed and functionally active only at intercalated discs and lateral surface membrane (Garciarena et al., 2013a). Taking into account the stoichiometry of NBCe1, claimed as a " $\mathrm{Na}^{+}$- sparing" bicarbonate transporter, it is feasible to anticipate that this selective distribution of the alkalinizing transporters and their relationship with the NCX may help to reduce the possibility of local $\mathrm{Ca}^{2+}$ overload near the sarcoplasmatic reticulum (SR), as recently suggested by Dr. Vaughan-Jones's group (Garciarena et al., 2013a). Interestingly, as it will be further discussed in this review, our group recently showed that NBCe1 activity is impaired whereas $\mathrm{NBCn} 1$ is overexpressed in the hypertrophied myocytes of spontaneous hypertensive rats (SHR) (Orlowski et al., 2013). It is also known that NHE-1 activity is increased in SHR rats (Perez et al., 1995). More importantly, in a model of cardiac hypertrophy due to NHE-1 overexpression, the NHE- 1 is distributed all around the sarcolemma (Nakamura et al., 2008), further suggesting that the pathological remodeling of these transporters could be, at least in part, responsible for the $\left[\mathrm{Na}^{+}\right]_{i}$ and $\left[\mathrm{Ca}^{2+}\right]_{i}$ overload-mediated cardiac hypertrophy (Garciarena et al., 2013b) (Figure 2).

\section{DIFFERENT PARTICIPATION OF NBCn1 AND NBCe1 IN pH $i$ REGULATION}

Cardiac NBC was initially described by Lagadic-Gossmann et al. as an electroneutral transporter (at present known as NBCn1) (Lagadic-Gossmann et al., 1992). Some years later Dr. Cingolani's group demonstrated that cardiac NBC also exhibits an electrogenic behavior (at present called NBCe1) (Camilion De Hurtado et al., 1995). Finally, it was demonstrated that both isoforms coexist in the heart and the fact that the NBC can mediate either the electroneutral or electrogenic bicarbonate transport enlarged the spectrum of research around it.

It has been described and characterized the rat and cat cardiac NBCel current as an anionic bicarbonate and sodium-dependent current which reversed at around $-85 \mathrm{mV}$ ( $\mathrm{I}_{\mathrm{NBC}}$ ) (Aiello et al., 1998; Villa-Abrille et al., 2007). Reversal potential for electrogenic NBC was also measured and estimated for rabbit, mouse and guinea pig, with values ranging from -98 to $-106 \mathrm{mV}$ (Yamamoto et al., 2005; Vaughan-Jones et al., 2006). It has also been described the influence of $\mathrm{NBCe} 1$ in the configuration of the cardiac action potential (CAP) (Aiello et al., 1998; VillaAbrille et al., 2007). Using the patch-clamp technique, it was demonstrated that the change of the extracellular solution from a HEPES- ( $\mathrm{HCO}_{3}^{-}$-free solution) to a $\mathrm{HCO}_{3}^{-}$-containing solution, hyperpolarized resting membrane potential (RMP) by $3-5 \mathrm{mV}$ and evoked a 25\% CAP shortening, both in rat (Aiello et al., 1998) and cat (Villa-Abrille et al., 2007) ventricular myocytes. Furthermore, Ang II inhibits NBCe1 current and prolongs CAP (De Giusti et al., 2010). In this regard, it is well-known that CAP prolongation is associated either as the initiator (Lebeche et al., 2006) or the consequence of the cardiac hypertrophy and arrhythmogenesis (Fischer et al., 2007; Weisser-Thomas et al., 2007). The outward current mediated by NBCe1, which under normal conditions shortens the CAP, might represent a protective aspect for the myocyte. 


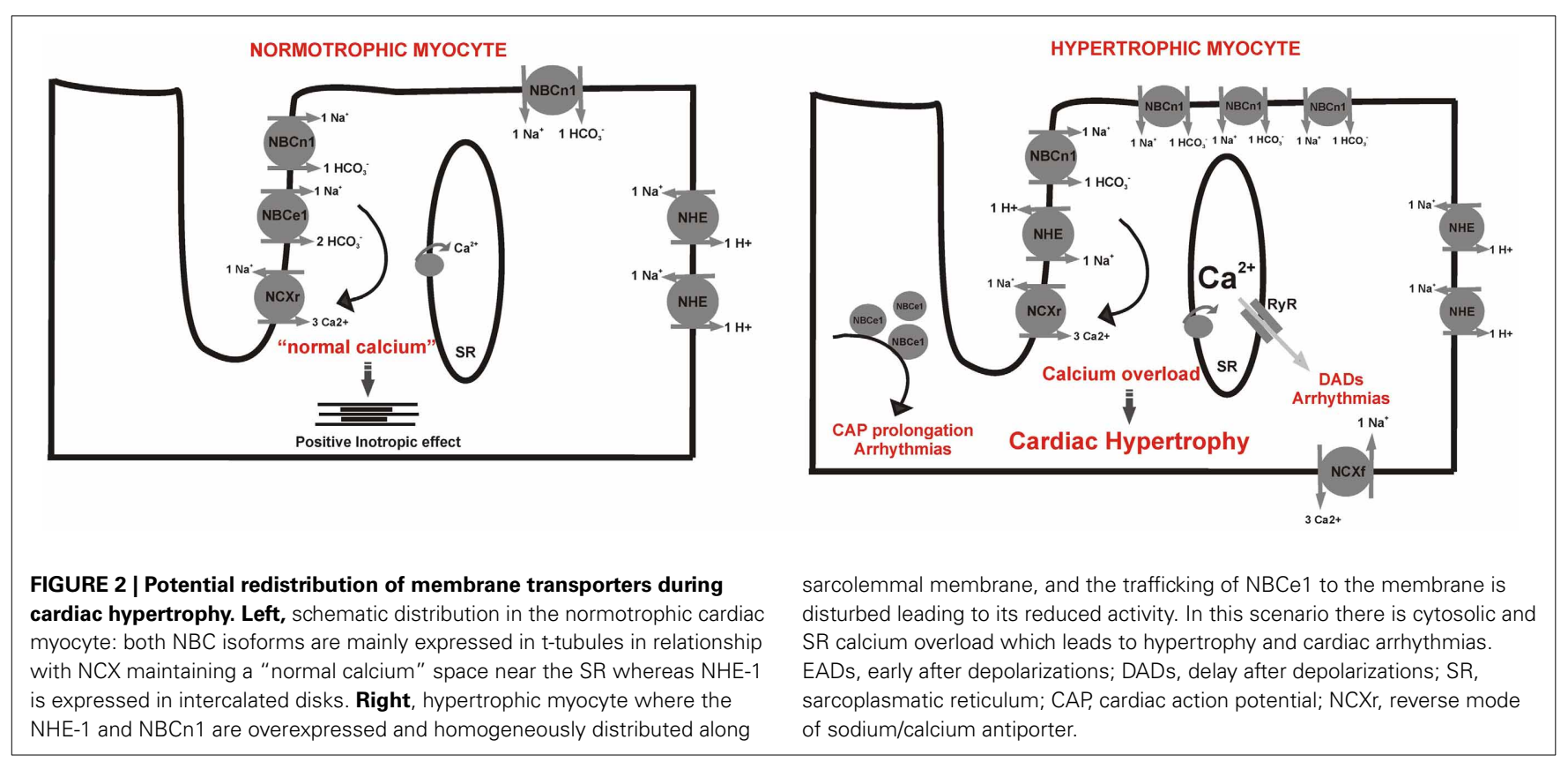

Important for the improvement of the knowledge about NBC, it was first described a selective blocker of the transporter (Ch'en et al., 2008), and some years later, specific antibodies against the NBCe1 that allowed the discrimination of the participation of each isoform in $\mathrm{pH}_{i}$ regulation were generated in our laboratory (De Giusti et al., 2011b). Two different and selective functional antibodies against NBCel were produced and characterized that were called a-L3 and a-L4 because they recognized the extracellular loop 3 and loop 4, respectively. Interestingly, these antibodies exhibited opposite effects on NBCe1 function, a-L3 totally inhibits NBCe1 activity, while a-L4 has an excitatory effect on it. In such research it was confirmed that NBCel is the only functional electrogenic alkalinizing mechanism in normal cardiac ventricular myocytes. Moreover, since a-L3 reduced proton efflux $\left(J_{H}\right)$ during the recovery from intracellular acidosis in an extracellular medium in the presence of bicarbonate and cariporide (NHE-1 blocker) by approximately $50 \%$, it could be speculated that, at least in rat and cat cardiomyoytes, both isoforms of the NBC, NBCe1, and NBCn1, exhibit an equivalent contribution to the regulation of $\mathrm{pH}_{i}$ under physiological conditions (De Giusti et al., 2011b; Orlowski et al., 2013).

\section{RENIN ANGIOTENSIN ALDOSTERONE SYSTEM: ENDOCRINE vs. PARACRINE SYSTEM}

Ang II is an octapeptide that classically was known to be synthesized from Ang I by the angiotensin-converting enzyme (ACE) present in the endothelial vessels in response to high levels of aldosterone, forming the endocrine system known as reninangiotensin-aldosterone-system (RAAS). However, at present it is well-recognized that Ang II is produced and secreted locally in the heart (Husain et al., 1994; Shyu et al., 2001). Furthermore, it was shown that $>75 \%$ of cardiac Ang II was synthesized locally, and that its source was also in situ-synthesized Ang I (De Mello and Danser, 2000). Although still controversial (Silvestre et al.,
1998, 1999; Takeda et al., 2000; Gomez-Sanchez et al., 2004; Chai and Danser, 2006), it has been also demonstrated that aldosterone synthase exists in the myocytes (Silvestre et al., 1998), supporting the existence of a local RAAS (Varagic and Frohlich, 2002). Dr. Sadoshima's group has shown that Ang II generates cardiac hypertrophy in response to myocardial stretch and secretion from intracellular vesicles (Sadoshima et al., 1993; Sadoshima and Izumo, 1996). Furthermore, Dr. Cingolani's group has deeply investigated the presence of this autocrine pathway as responsible for the SFR to myocardial stretch, proposing the NHE-1 as the final effector. (Cingolani et al., 2001, 2003). Moreover, aldosterone has been shown to activate NHE-1, (De Giusti et al., 2011a) and to increase NHE-1 expression, inducing left ventricular hypertrophy (Karmazyn et al., 2003), independently from its classical effects on regulation of renal $\mathrm{Na}^{+}$excretion and blood pressure (Qin et al., 2003; Yoshida et al., 2005; Diez, 2008). In addition, the investigation of the role of aldosterone in cardiac pathophysiology has gained increasing interest in the last few years due to relevant results obtained from clinical studies, particularly RALES (Randomized Aldactone Evaluation Study), EPHESUS (Eplerenone Post-acute Myocardial Infarction Heart Failure Efficacy and Survival Study), and EMPHASIS-HF, in which antagonists of the MR importantly reduced mortality in patients with left ventricular dysfunction independently of the values of blood pressure (Pitt et al., 1999, 2001; London et al., 2003).

Classically, aldosterone enters the cells and binds to the MR located mainly in the cytosol. This binding translocates the MR to the nucleus, where it acts as a ligand-induced transcription factor. However, it has been proposed that activated MR can elicit additional non-classical effects, which do not require transcription or translation of genes and involved the production of ROS (Caldiz et al., 2011), leading to the activation of ions membrane transporters (Ebata et al., 1999; Mihailidou et al., 2004; Chai et al., 
2005; Grossmann and Gekle, 2009; Caldiz et al., 2011; De Giusti et al., 2011a). The mechanisms conveying theses rapid and nongenomics effects consist in several signaling cascades of kinases, as protein kinase C (PKC) (Ebata et al., 1999; Mihailidou et al., 2004) and ERK $1 / 2$ (Caldiz et al., 2011), and also include a crosstalk with Ang II (Lemarie et al., 2008; Rautureau et al., 2011) and the transactivation of EGFR (Grossmann et al., 2010; De Giusti et al., 2011a). Moreover, it has been proposed the presence of a crosstalk between both, genomic and non-genomic pathways of aldosterone (Grossmann and Gekle, 2009). On the other hand, it was recently demonstrated that certain non-genomic effects of aldosterone in vascular smooth muscle were due to simultaneous activation of MR and a surface membrane $G$ protein-coupled receptor, the GPR30 (Gros et al., 2011, 2013). In agreement, growing evidence is appearing which demonstrate that GPR30 could be another aldosterone receptor involved in the rapid effects of the hormone in the cardiovascular system (Gros et al., 2011; Meyer et al., 2011).

\section{REGULATION OF NBC BY RAAS}

It was demonstrated that Ang II stimulates total NBC activity, both in rat (Baetz et al., 2002) and cat (De Giusti et al., 2009) ventricular myocytes in a ROS- (De Giusti et al., 2009)and ERK 1/2-dependent manner (Baetz et al., 2002; De Giusti et al., 2009). Moreover, the phenomenon known as "ROS-inducedROS-release," where a small amount of ROS derived from NADPH oxidase (NOX) stimulates mitochondria to produce and release a burst of ROS (Zorov et al., 2000, 2006; Kimura et al., 2005), was also involved in Ang II-induced NBC stimulation (De Giusti et al., 2009).

Our group demonstrated for the first time a differential effect of Ang II on NBC isoforms through parallel pathways(De Giusti et al., 2010). Ang II after binding to AT-1 receptor inhibits NBCe1 in a p38 kinase-dependent, whereas activates NBCn1 via an ERK $1 / 2$ and ROS-dependent mechanism (Figure 1). Furthermore, Ang II generated a higher increase in $J_{H}$ in the presence of p38 kinase inhibitor than in its absence, leading us to the speculation that Ang II-induced stimulation of NBCn1 overrules the inhibition of NBCe1 (Aiello and De Giusti, 2013). Interestingly, Ang II abrogated the anionic current generated by the NBCe1 (De Giusti et al., 2010). It is well-known that Ang II induces CAP prolongation which leads to arrhythmic effects (Fischer et al., 2007). Thus, it is possible to speculate that this inhibition of NBCe1 by Ang II might be involved, at least in part, in the CAP prolongation and arrhythmias induced by this hormone (Figure 1).

It has been reported that aldosterone stimulates NHE-1 via $\mathrm{MR}$ in a non-genomic manner and via a ROS-dependent pathway (Caldiz et al., 2011; De Giusti et al., 2011a). As NBC activity was shown to be ROS (De Giusti et al., 2009) and ERK $1 \frac{1}{2}$ kinasedependent (Baetz et al., 2002), it might be possible to speculate that aldosterone can regulate NBC. Interestingly, Gros et al. have demonstrated that aldosterone mediates its rapid effects in vascular endothelial cells through GPR30 activation (Gros et al., 2013). Moreover, it was reported that GPR30 is expressed in the heart (Bopassa et al., 2010) and that the stimulation of this receptor by estradiol (Patel et al., 2010) or G1, a specific GPR30 agonist, (Deschamps and Murphy, 2009; Bopassa et al., 2010) mediates protection during ischemia-reperfusion injury (Deschamps et al., 2010). Whether the potential effect of aldosterone on cardiac NBC could be mediated through MR or GPR30 activation represents an interesting issue that deserves future investigation.

\section{INVOLVEMENT OF NBC IN RAAS INDUCED CARDIAC DISEASES}

Aberrant $\mathrm{H}^{+}$-induced $\mathrm{Na}^{+}$and $\mathrm{Ca}^{2+}$ influxes has been proposed to participate in maladaptive cardiac hypertrophy (Yamamoto et al., 2007; Baartscheer and Van Borren, 2008; Cingolani et al., 2008) and arrhythmogenesis (Baartscheer et al., 2008). In the last years, NBC disturbances were described during cardiac hypertrophy in close relationship with RAAS activation (Yamamoto et al., 2007; Orlowski et al., 2013). Moreover, there is enough information about the involvement of $\mathrm{Na}^{+}$(Gonano et al., 2011) and $\mathrm{Ca}^{2+}$ signaling disorders (Venetucci et al., 2008) and Ang II stimulation (Zhao et al., 2011) in the genesis of arrhythmias. However, until present and besides NBC activity influence on $\left[\mathrm{Na}^{+}\right]_{i}$ and $\left[\mathrm{Ca}^{2+}\right]_{i}$, nothing is known about the direct involvement of NBC in arrhythmogenesis.

\section{IS NBC INVOLVED IN CARDIAC HYPERTROPHY?}

Yamamoto et al have demonstrated that NBCe1 and NBCn1 were over-expressed in ventricular myocytes isolated from hypertrophied rat hearts subjected to non-ischemic pressure overload and that these changes were prevented by the AT-1 blocker Losartan (Yamamoto et al., 2007). However, a clear up-regulation of NBCe1 activity could not be demonstrated (Yamamoto et al., 2007). In addition, it has been reported that, although NBCe1 was also over-expressed in hypertrophied hearts of SHR rats, its activity was impaired (Orlowski et al., 2013). It was proposed that Ang II-induced NBCe1 internalization might explain the discordance between protein expression and transport activity (Orlowski et al., 2013) (Figure 1). Interestingly, in the same research it was suggested that $\mathrm{NBCn} 1$ activity was increased in order to maintain $\mathrm{pH}_{i}$. However, based in the different stoichiometry of both isoforms, this remodeling might lead to higher $\mathrm{Na}^{+}$ influx and in consequence greater intracellular calcium overload. In agreement with the hypothesis that NBCe1 could be internalized during cardiac hypertrophy, it has been described that Ang II promotes NBCe1 internalization in Xenopus oocytes transfected with this NBC isoform (Perry et al., 2007). Consistently, the differential membrane expression and function of NBC isoforms observed in the hearts of SHR rats were reversed by treatment of these hypertensive rats with losartan (Orlowski et al., 2013).

It is well-known that increased $\left[\mathrm{Ca}^{2+}\right]_{i}$ activates hypertrophic pathways, such as the one of calcineurin (Ennis et al., 2007; Guo et al., 2011). $\mathrm{Ca}^{2+}$ regulation is closely linked to $\left[\mathrm{Na}^{+}\right]_{i}$ because one of the routes for $\mathrm{Ca}^{2+}$ influx into the myocytes is via NCXr. During acidosis there is an intimate link between $\mathrm{Na}^{+}$and $\mathrm{Ca}^{2+}$, mediated through a functional coupling among the activities of the alkalinizing transporters and NCX (Garciarena et al., 2013a).

In animal models of hypertrophy, as well as in human heart failure, it has been demonstrated an increase in $\left[\mathrm{Na}^{+}\right]_{i}$ and $\left[\mathrm{Ca}^{2+}\right]_{i}$ (Gray et al., 2001; Despa et al., 2002; Verdonck et al., 2003). Furthermore, it was shown that chronic NHE-1 inhibition, which attenuates $\left[\mathrm{Na}^{+}\right]_{i}$ overload, restrains $\mathrm{Ca}^{2+}$ activated 
pro-hypertrophic intracellular pathways and reverses myocardial remodeling, leading to prevention or reversion of cardiac hypertrophy (Kusumoto et al., 2001; Camilion De Hurtado et al., 2002; Engelhardt et al., 2002; Ennis et al., 2003). Furthermore, it was demonstrated that the over-expression of NHE-1 alone is enough to induce cardiac hypertrophy in a murine model (Nakamura et al., 2008). Interestingly, these animals presented a higher NHE1 expression, not only at intercalated discs, where it is normally expressed, but also all along the transverse tubules (Nakamura et al., 2008). Inappropriate trafficking of NBC may also be exacerbated by the increasing loss of t-tubules from ventricular cells in the progression to heart failure (Wei et al., 2010). In this regard, the normal selective spatial distribution of the alkalinizing transporters is crucial for the ion homeostasis, suggesting that the impairment of this distribution might be detrimental for myocyte function (Figure 2) (Garciarena et al., 2013a).

NBC is responsible for $30 \%$ of $\mathrm{Na}^{+}$influx into the myocyte at $\mathrm{pH}_{i} 6.8$ (Vaughan-Jones et al., 2006), so it may be also important to the development of cardiac hypertrophy. In this regard and as it was commented above, it has been shown that NBCn1 function is up-regulated in cardiac hypertrophy (Yamamoto et al., 2007), while NBCe1 transport seems to be impaired in the hypertrophied heart of SHR rats (Orlowski et al., 2013). Taking into account that NBCe1 has $\mathrm{Na}^{+}$-sparing activity, it is feasible to anticipate that this remodeling of NBC isoforms in hypertrophied hearts would lead to more $\left[\mathrm{Na}^{+}\right]_{i}$ and $\left[\mathrm{Ca}^{2+}\right]_{i}$ overload. Moreover, the distribution of $\mathrm{NBCe} 1$ along the transverse tubules clustered with the NCX and the sarcoplasmic reticulum (SR), the most important pool of $\mathrm{Ca}^{2+}$, proposes a relevant relationship between this NBC isoform and calcium handling. Furthermore, it was reported that luminal SR $\left[\mathrm{Ca}^{2+}\right]$ is $\mathrm{Na}^{+}{ }_{i}$ sensitive, suggesting that the tubular NBC activity may allow to create a local control of $\mathrm{pH}_{i}$ while minimizing the effects of local $\mathrm{Na}^{+}$-loading on $\mathrm{Ca}^{2+}$ signaling (Garciarena et al., 2013a).

Another important aspect that should be taken into account is the possibility that the NBCe1 downregulation observed in SHR hypertrophic hearts may lead, not only to membrane overexpression of NBCn1, but also to an enhanced NHE-1 activity. Since a hyperactivity of NHE-1 in myocardium of SHR has been previously demonstrated (Perez et al., 1995), it might be interesting to elucidate if both phenomena are related and furthermore, if NBCe1 downregulation is the cause of NHE-1 hyperactivity in this strain.

\section{IS NBC INVOLVED IN EARLY AND DELAYED AFTER DEPOLARIZATIONS (EADs AND DADs)?}

It has been shown that either the inhibition of the $\mathrm{Na}^{+} / \mathrm{K}^{+}$ATPase (Sedej et al., 2010; Gonano et al., 2011) or the NHE-1 stimulation (Baartscheer et al., 2008) generates $\left[\mathrm{Na}^{+}\right]_{i}$ overload which leads to cardiac arrhythmias due to the reduction of $\mathrm{Ca}^{2+}$ extrusion and/or the increase of $\mathrm{Ca}^{2+}$ influx through the NCX. The increase in $\left[\mathrm{Ca}^{2+}\right]_{i}$ enhances the SR calcium load, leading to spontaneous diastolic calcium release. Then, the increase in cytosolic $\mathrm{Ca}^{2+}$ (waves) activates an inward (depolarizing) current $\left(\mathrm{I}_{t i}\right)$, mediated by the forward mode of NCX (NCXf) (Bers et al., 2002; Rizzi et al., 2008). $\mathrm{I}_{t i}$ is responsible for the generation of the delayed after depolarizations (DADs) which, when are sufficiently large to achieve the threshold, generate spontaneous CAP, leading to triggered activity (Liu et al., 2011).

As NBC activity promotes the increase in $\left[\mathrm{Na}^{+}\right]_{i}$ (VaughanJones et al., 2006), it is also possible to speculate that Ang II and ROS-induced NBCn1 stimulation (De Giusti et al., 2009, 2010) might be implicated in DADs generation (Figure 1). According to this, it was demonstrated that Ang II induces DADs in a ROSdependent manner (Wiederkehr et al., 1999).

Classically, Ang II is known to modulate the properties of ion channels involved in the cardiac action potential (CAP) configuration (Vila Petroff et al., 2000; Salas et al., 2001; Domenighetti et al., 2007; Rivard et al., 2008). It has been reported that Ang II prolongs CAP both, inhibiting repolarizing currents as $\mathrm{I}_{\mathrm{K} 1}$, $\mathrm{I}_{\mathrm{Kr}}$, and $\mathrm{I}_{\text {to }}$ (Zhou et al., 2006; Domenighetti et al., 2007; Rivard et al., 2008; Wang et al., 2008) and stimulating depolarizing currents as $\mathrm{I}_{\mathrm{CaL}}$ (Aiello and Cingolani, 2001; Ichiyanagi et al., 2002). Moreover, it has been recently demonstrated that Ang II abrogated the NBCel-induced CAP shortening, likely due to the inhibition of the repolarizing current generated by the transporter (De Giusti et al., 2010). In this regard, it has been shown that CAP prolongation enhances the occurrence of early after depolarizations (EADs), due to the recovery from the inactivation and the reactivation of voltage-dependent L-type $\mathrm{Ca}^{2+}$ channels (Nuss et al., 1999; Wiederkehr et al., 1999; Xie et al., 2009) and the impairment of sodium current (Wiederkehr et al., 1999; Xie et al., 2009). In concordance, Ang II was shown to increase the occurrence of EADs in a ROS and CaMKII-dependent manner (Zhao et al., 2011), suggesting the possibility that Ang IIinduced NBCe1 inhibition might participate in the generation of EADs.

In summary, it might be also possible that Ang II-induced NBCel inhibition and NBCn 1 stimulation participate in the generation of EAD, secondary to CAP prolongation and $\left[\mathrm{Na}^{+}\right]_{i}$ overload, respectively (Figure 1).

It is known that a close relationship exist between CAP prolongation and hypertrophy, but it is unclear which is cause and which the consequence. On the one hand, the CAP prolongation is consistently observed in several experimental models of cardiac hypertrophy and failure (Carmeliet, 2006). It is also known that this can lead to QT prolongation, which is the basis of arrhytmogenic events (Fischer et al., 2007; Baartscheer et al., 2008). On the other hand, Lebeche et al have reported that CAP prolongation promotes an increase in $\left[\mathrm{Ca}^{2+}\right]_{i}$, which activates a hypertrophic signaling pathway that might be a cause and not a consequence of cardiac hypertrophy (Lebeche et al., 2006).

\section{FINAL CONCLUSION}

The purpose of this review is to focus the attention on the cardiac $\mathrm{NBC}$ and its regulation by RAAS, especially considering the implications of this modulation in cardiac diseases. Classically, NBC is known as an alkalinizing mechanism. However, it is important to keep in mind that this is not its only function but it also controls $\left[\mathrm{Na}^{+}\right]_{i}$, and indirectly $\left[\mathrm{Ca}^{2+}\right]_{i}$ through the NCX activity and SR behavior. Moreover, NBCel modulates the shape and duration of the CAP, adding to this isoform the important role of contributing to cellular electrophysiology. As RAAS exerts a central role in cardiac pathophysiology, it can be considered of significant 
relevance the fact that both hormones, Ang II and possibly aldosterone, regulate NBC activity. Moreover, Ang II seems to regulate the trafficking of NBC besides the influence in the transporter activity (Perry et al., 2007; Orlowski et al., 2013). Moreover, Ang II exerting an opposite effect on NBC isoforms, might be doubly detrimental, leading to $\mathrm{Na}^{+}$and $\mathrm{Ca}^{2+}$ overload and CAP prolongation, which could be relevant, at least in part, to explain the hypertrophic and arrthymogenic effects of the hormone. Until present, it is not known if aldosterone can induce NBC stimulation via the activation of the electrogenic, the electroneutral or both isoforms of NBC. This issue might be kept in consideration because of the different role of each isoform in myocyte physiology.

The knowledge of the central role that sodium and calcium concentrations play and the close relationship between them and $\mathrm{H}^{+}$movements with NBC expression and distribution, forces us to keep the attention in NBC and cardiac diseases. Furthermore, the fact that RAAS exerts direct effects on NBC activity strengthens the conviction that NBC might be responsible, at least in part, for the development and maintenance of cardiac diseases.

\section{REFERENCES}

Aiello, E. A., and Cingolani, H. E. (2001). Angiotensin II stimulates cardiac L-type $\mathrm{Ca}^{2+}$ current by a $\mathrm{Ca}^{2+}$ - and protein kinase C-dependent mechanism. Am. J. Physiol. Heart Circ. Physiol. 280, H1528-H1536.

Aiello, E. A., and De Giusti, V. C. (2013). Regulation of the cardiac sodium/bicarbonate cotransporter by angiotensin II: potential contribution to structural, ionic and electrophysiological myocardial remodelling. Curr. Cardiol. Rev. 9, 24-32. doi: 10.2174/1573403X11309010005

Aiello, E. A., Petroff, M. G., Mattiazzi, A. R., and Cingolani, H. E. (1998). Evidence for an electrogenic $\mathrm{Na}^{+}-\mathrm{HCO}_{3}^{-}$symport in rat cardiac myocytes. J. Physiol. 512(Pt 1), 137-148. doi: 10.1111/j.1469-7793.1998.137bf.x

Aiello, E. A., Villa-Abrille, M. C., Dulce, R. A., Cingolani, H. E., and Perez, N. G. (2005). Endothelin-1 stimulates the $\mathrm{Na}^{+} / \mathrm{Ca}^{2+}$ exchanger reverse mode through intracellular $\mathrm{Na}^{+}\left(\mathrm{Na}^{+}{ }_{i}\right)$-dependent and $\mathrm{Na}^{+}{ }_{i}$-independent pathways. Hypertension 45, 288-293. doi: 10.1161/01.HYP.0000152700. 58940.b2

Baartscheer, A., Hardziyenka, M., Schumacher, C. A., Belterman, C. N., Van Borren, M. M., Verkerk, A. O., et al. (2008). Chronic inhibition of the $\mathrm{Na}^{+} / \mathrm{H}^{+}$- exchanger causes regression of hypertrophy, heart failure, and ionic and electrophysiological remodelling. Br. J. Pharmacol. 154, 1266-1275. doi: 10.1038/bjp.2008.189

Baartscheer, A., and Van Borren, M. M. (2008). Sodium ion transporters as new therapeutic targets in heart failure. Cardiovasc. Hematol. Agents Med. Chem. 6, 229-236. doi: 10.2174/187152508785909546

Baetz, D., Haworth, R. S., Avkiran, M., and Feuvray, D. (2002). The ERK pathway regulates $\mathrm{Na}^{+}-\mathrm{HCO}_{3}^{-}$cotransport activity in adult rat cardiomyocytes. Am. J. Physiol. Heart Circ. Physiol. 283, H2102-H2109. doi: 10.1152/ajpheart.01071. 2001

Barbato, J. C., Mulrow, P. J., Shapiro, J. I., and Franco-Saenz, R. (2002). Rapid effects of aldosterone and spironolactone in the isolated working rat heart. Hypertension 40, 130-135. doi: 10.1161/01.HYP.0000025879.29822.24

Barbato, J. C., Rashid, S., Mulrow, P. J., Shapiro, J. I., and Franco-Saenz, R. (2004). Mechanisms for aldosterone and spironolactone-induced positive inotropic actions in the rat heart. Hypertension 44, 751-757. doi: 10.1161/01.HYP.0000144466.11568.7e

Bers, D. M., Pogwizd, S. M., and Schlotthauer, K. (2002). Upregulated $\mathrm{Na} / \mathrm{Ca}$ exchange is involved in both contractile dysfunction and arrhythmogenesis in heart failure. Basic Res. Cardiol. 97(Suppl. 1), I36-I42. doi: 10.1007/s003950200027

Bopassa, J. C., Eghbali, M., Toro, L., and Stefani, E. (2010). A novel estrogen receptor GPER inhibits mitochondria permeability transition pore opening and protects the heart against ischemia-reperfusion injury. Am. J. Physiol. Heart Circ. Physiol. 298, H16-H23. doi: 10.1152/ajpheart.00588.2009
Bountra, C., Kaila, K., and Vaughan-Jones, R. D. (1988). Effect of repetitive activity upon intracellular $\mathrm{pH}$, sodium and contraction in sheep cardiac Purkinje fibres. J. Physiol. 398, 341-360.

Bril, A. (2003). [Ion transporters and cardiovascular diseases: pH control or modulation of intracellular calcium concentration]. Ann. Cardiol. Angeiol. 52, 41-51. doi: 10.1016/S0003-3928(02)00182-8

Caldiz, C. I., Diaz, R. G., Nolly, M. B., Chiappe De Cingolani, G. E., Ennis, I. L., Cingolani, H. E., et al. (2011). Mineralocorticoid receptor activation is crucial in the signalling pathway leading to the Anrep effect. J. Physiol. 589, 6051-6061. doi: 10.1113/jphysiol.2011.218750

Camilion De Hurtado, M. C., Perez, N. G., and Cingolani, H. E. (1995). An electrogenic sodium-bicarbonate cotransport in the regulation of myocardial intracellular pH. J. Mol. Cell. Cardiol. 27, 231-242.

Camilion De Hurtado, M. C., Portiansky, E. L., Perez, N. G., Rebolledo, O. R., and Cingolani, H. E. (2002). Regression of cardiomyocyte hypertrophy in SHR following chronic inhibition of the $\mathrm{Na}^{+} / \mathrm{H}^{+}$exchanger. Cardiovasc. Res. 53, 862-868. doi: 10.1016/S0008-6363(01)00544-2

Carmeliet, E. (2006). Action potential duration, rate of stimulation, and intracellular sodium. J. Cardiovasc. Electrophysiol. 17(Suppl. 1), S2-S7. doi: 10.1111/j.1540-8167.2006.00378.x

Chai, W., and Danser, A. H. (2006). Why are mineralocorticoid receptor antagonists cardioprotective? Naunyn Schmiedebergs. Arch. Pharmacol. 374, 153-162. doi: 10.1007/s00210-006-0107-9

Chai, W., Garrelds, I. M., Arulmani, U., Schoemaker, R. G., Lamers, J. M., and Danser, A. H. (2005). Genomic and nongenomic effects of aldosterone in the rat heart: why is spironolactone cardioprotective? Br. J. Pharmacol. 145, 664-671. doi: 10.1038/sj.bjp.0706220

Ch'en, F. F., Villafuerte, F. C., Swietach, P., Cobden, P. M., and VaughanJones, R. D. (2008). S0859, an N-cyanosulphonamide inhibitor of sodiumbicarbonate cotransport in the heart. Br. J. Pharmacol. 153, 972-982. doi: 10.1038/sj.bjp.0707667

Cingolani, H. E., Perez, N. G., Aiello, E. A., Ennis, I. L., Garciarena, C. D., Villa-Abrille, M. C., et al. (2008). Early signals after stretch leading to cardiac hypertrophy. Key role of NHE-1. Front. Biosci. 13, 7096-7114. doi: 10.2741/3213

Cingolani, H. E., Perez, N. G., and Camilion De Hurtado, M. C. (2001). An autocrine/paracrine mechanism triggered by myocardial stretch induces changes in contractility. News Physiol. Sci. 16, 88-91.

Cingolani, H. E., Perez, N. G., Cingolani, O. H., and Ennis, I. L. (2013). The Anrep effect: 100 years later. Am. J. Physiol. Heart Circ. Physiol. 15, H175-H182. doi: 10.1152/ajpheart.00508.2012

Cingolani, H. E., Perez, N. G., Pieske, B., Von Lewinski, D., and Camilion De Hurtado, M. C. (2003). Stretch-elicited $\mathrm{Na}^{+} / \mathrm{H}^{+}$exchanger activation: the autocrine/paracrine loop and its mechanical counterpart. Cardiovasc. Res. 57, 953-960. doi: 10.1016/S0008-6363(02)00768-X

De Giusti, V. C., Garciarena, C. D., and Aiello, E. A. (2009). Role of reactive oxygen species (ROS) in angiotensin II-induced stimulation of the $\operatorname{ardiac~} \mathrm{Na}^{+} / \mathrm{HCO}_{3}^{-}$ cotransport. J. Mol. Cell. Cardiol. 47, 716-722. doi: 10.1016/j.yjmcc.2009.07.023

De Giusti, V. C., Nolly, M. B., Yeves, A. M., Caldiz, C. I., Villa-Abrille, M. C., Chiappe De Cingolani, G. E., et al. (2011a). Aldosterone stimulates the cardiac $\mathrm{Na}^{+} / \mathrm{H}^{+}$exchanger via transactivation of the epidermal growth factor receptor. Hypertension 58, 912-919. doi: 10.1161/HYPERTENSIONAHA.111.176024

De Giusti, V. C., Orlowski, A., Villa-Abrille, M. C., De Cingolani, G. E., Casey, J. R., Alvarez, B. V., et al. (2011b). Antibodies against the cardiac sodium/bicarbonate co-transporter (NBCe1) as pharmacological tools. Br. J. Pharmacol. 164, 1976-1989. doi: 10.1111/j.1476-5381.2011.01496.x

De Giusti, V. C., Orlowski, A., and Aiello, E. A. (2010). Angiotensin II inhibits the electrogenic $\mathrm{Na}^{+} / \mathrm{HCO}_{3}^{-}$cotransport of cat cardiac myocytes. J. Mol. Cell. Cardiol. 49, 812-818. doi: 10.1016/j.yjmcc.2010.07.018

De Mello, W. C., and Danser, A. H. (2000). Angiotensin II and the heart: on the intracrine renin-angiotensin system. Hypertension 35, 1183-1188. doi: 10.1161/01.HYP.35.6.1183

Deschamps, A. M., and Murphy, E. (2009). Activation of a novel estrogen receptor, GPER, is cardioprotective in male and female rats. Am. J. Physiol. Heart Circ. Physiol. 297, H1806-H1813. doi: 10.1152/ajpheart.00283.2009

Deschamps, A. M., Murphy, E., and Sun, J. (2010). Estrogen receptor activation and cardioprotection in ischemia reperfusion injury. Trends Cardiovasc. Med. 20, 73-78. doi: 10.1016/j.tcm.2010.05.001

Despa, S., Islam, M. A., Weber, C. R., Pogwizd, S. M., and Bers, D. M. (2002). Intracellular $\mathrm{Na}^{+}$concentration is elevated in heart failure 
but $\mathrm{Na} / \mathrm{K}$ pump function is unchanged. Circulation 105, 2543-2548. doi: 10.1161/01.CIR.0000016701.85760.97

Diez, J. (2008). Effects of aldosterone on the heart: beyond systemic hemodynamics? Hypertension 52, 462-464. doi: 10.1161/HYPERTENSIONAHA.108. 117044

Domenighetti, A. A., Boixel, C., Cefai, D., Abriel, H., and Pedrazzini, T. (2007). Chronic angiotensin II stimulation in the heart produces an acquired long QT syndrome associated with IK1 potassium current downregulation. J. Mol. Cell. Cardiol. 42, 63-70. doi: 10.1016/j.yjmcc.2006.09.019

Dulce, R. A., Hurtado, C., Ennis, I. L., Garciarena, C. D., Alvarez, M. C., Caldiz, C., et al. (2006). Endothelin-1 induced hypertrophic effect in neonatal rat cardiomyocytes: involvement of $\mathrm{Na}^{+} / \mathrm{H}^{+}$and $\mathrm{Na}^{+} / \mathrm{Ca}^{2+}$ exchangers. J. Mol. Cell. Cardiol. 41, 807-815. doi: 10.1016/j.yjmcc.2006.05.016

Ebata, S., Muto, S., Okada, K., Nemoto, J., Amemiya, M., Saito, T., et al. (1999). Aldosterone activates $\mathrm{Na}^{+} / \mathrm{H}^{+}$exchange in vascular smooth muscle cells by nongenomic and genomic mechanisms. Kidney Int. 56, 1400-1412. doi: 10.1046/j.1523-1755.1999.00674.x

Elliott, A. C., Smith, G. L., and Allen, D. G. (1994). The metabolic consequences of an increase in the frequency of stimulation in isolated ferret hearts. J. Physiol. 474, 147-159.

Engelhardt, S., Hein, L., Keller, U., Klambt, K., and Lohse, M. J. (2002). Inhibition of $\mathrm{Na}^{+}-\mathrm{H}^{+}$exchange prevents hypertrophy, fibrosis, and heart failure in beta(1)-adrenergic receptor transgenic mice. Circ. Res. 90, 814-819. doi: 10.1161/01.RES.0000014966.97486.C0

Ennis, I. L., Escudero, E. M., Console, G. M., Camihort, G., Dumm, C. G., Seidler, R. W., et al. (2003). Regression of isoproterenol-induced cardiac hypertrophy by $\mathrm{Na}^{+} / \mathrm{H}^{+}$exchanger inhibition. Hypertension 41, 1324-1329. doi: 10.1161/01.HYP.0000071180.12012.6E

Ennis, I. L., Garciarena, C. D., Escudero, E. M., Perez, N. G., Dulce, R. A., Camilion De Hurtado, M. C., et al. (2007). Normalization of the calcineurin pathway underlies the regression of hypertensive hypertrophy induced by $\mathrm{Na}^{+} / \mathrm{H}^{+}$ exchanger-1 (NHE-1) inhibition. Can. J. Physiol. Pharmacol. 85, 301-310. doi: 10.1139/y06-072

Fischer, R., Dechend, R., Gapelyuk, A., Shagdarsuren, E., Gruner, K., Gruner, A., et al. (2007). Angiotensin II-induced sudden arrhythmic death and electrical remodeling. Am. J. Physiol. Heart Circ. Physiol. 293, H1242-H1253. doi: 10.1152/ajpheart.01400.2006

Garciarena, C. D., Ma, Y. L., Swietach, P., Huc, L., and Vaughan-Jones, R. D. (2013a). Sarcolemmal localisation of $\mathrm{Na}^{+} / \mathrm{H}^{+}$exchange and $\mathrm{Na}^{+}-\mathrm{HCO}_{3}^{-}$cotransport influences the spatial regulation of intracellular $\mathrm{pH}$ in rat ventricular myocytes. J. Physiol. 591, 2287-2306. doi: 10.1113/jphysiol.2012.249664

Garciarena, C. D., Youm, J. B., Swietach, P., and Vaughan-Jones, R. D. (2013b). $\mathrm{H}^{+}$-activated $\mathrm{Na}^{+}$influx in the ventricular myocyte couples $\mathrm{Ca}^{2+}$-signalling to intracellular pH. J. Mol. Cell. Cardiol. 61, 51-59. doi: 10.1016/j.yjmcc.2013.04.008

Garlick, P. B., Radda, G. K., and Seeley, P. J. (1979). Studies of acidosis in the ischaemic heart by phosphorus nuclear magnetic resonance. Biochem. J. 184, 547-554.

Gomez-Sanchez, E. P., Ahmad, N., Romero, D. G., and Gomez-Sanchez, C. E. (2004). Origin of aldosterone in the rat heart. Endocrinology 145, 4796-4802. doi: 10.1210/en.2004-0295

Gonano, L. A., Sepulveda, M., Rico, Y., Kaetzel, M., Valverde, C. A., Dedman, J., et al. (2011). Calcium-calmodulin kinase II mediates digitalisinduced arrhythmias. Circ. Arrhythm. Electrophysiol. 4, 947-957. doi: 10.1161/CIRCEP.111.964908

Gray, R. P., McIntyre, H., Sheridan, D. S., and Fry, C. H. (2001). Intracellular sodium and contractile function in hypertrophied human and guinea-pig myocardium. Pflugers Arch. 442, 117-123. doi: 10.1007/s004240000512

Gros, R., Ding, Q., Liu, B., Chorazyczewski, J., and Feldman, R. D. (2013). Aldosterone mediates its rapid effects in vascular endothelial cells through GPER activation. Am. J. Physiol. Cell Physiol. 304, C532-C540. doi: 10.1152/ajpcell.00203.2012

Gros, R., Ding, Q., Sklar, L. A., Prossnitz, E. E., Arterburn, J. B., Chorazyczewski, J., et al. (2011). GPR30 expression is required for the mineralocorticoid receptor-independent rapid vascular effects of aldosterone. Hypertension 57, 442-451. doi: 10.1161/HYPERTENSIONAHA.110.161653

Grossmann, C., and Gekle, M. (2009). New aspects of rapid aldosterone signaling. Mol. Cell. Endocrinol. 308, 53-62. doi: 10.1016/j.mce.2009.02.005
Grossmann, C., Husse, B., Mildenberger, S., Schreier, B., Schuman, K., and Gekle, M. (2010). Colocalization of mineralocorticoid and EGF receptor at the plasma membrane. Biochim. Biophys. Acta 1803, 584-590. doi: 10.1016/j.bbamcr.2010.02.008

Guo, J., Gan, X. T., Haist, J. V., Rajapurohitam, V., Zeidan, A., Faruq, N. S., et al. (2011). Ginseng inhibits cardiomyocyte hypertrophy and heart failure via NHE1 inhibition and attenuation of calcineurin activation. Circ. Heart Fail. 4, 79-88. doi: 10.1161/CIRCHEARTFAILURE.110.957969

Husain, A. K. A., Sung, S. S., Urata, H., and Bumpus, F. M. (1994). "Human heart chymase," in The Cardiac Renin-Angiotensin System, ed G. D. E. Lindpaintner (Armonk, NY: Futura Publishing), 309-332.

Ichiyanagi, O., Ishii, K., and Endoh, M. (2002). Angiotensin II increases L-type $\mathrm{Ca}^{2+}$ current in gramicidin D-perforated adult rabbit ventricular myocytes: comparison with conventional patch-clamp method. Pflugers Arch. 444, 107-116. doi: 10.1007/s00424-002-0808-y

Karmazyn, M., Liu, Q., Gan, X. T., Brix, B. J., and Fliegel, L. (2003). Aldosterone increases NHE-1 expression and induces NHE-1-dependent hypertrophy in neonatal rat ventricular myocytes. Hypertension 42, 1171-1176. doi: 10.1161/01.HYP.0000102863.23854.0B

Khandoudi, N., Albadine, J., Robert, P., Krief, S., Berrebi-Bertrand, I., Martin, X., et al. (2001). Inhibition of the cardiac electrogenic sodium bicarbonate cotransporter reduces ischemic injury. Cardiovasc. Res. 52, 387-396. doi: 10.1016/S0008-6363(01)00430-8

Kimura, S., Zhang, G. X., Nishiyama, A., Shokoji, T., Yao, L., Fan, Y. Y., et al. (2005). Role of $\mathrm{NAD}(\mathrm{P}) \mathrm{H}$ oxidase- and mitochondria-derived reactive oxygen species in cardioprotection of ischemic reperfusion injury by angiotensin II. Hypertension 45, 860-866. doi: 10.1161/01.HYP.0000163462.98381.7f

Kusumoto, K., Haist, J. V., and Karmazyn, M. (2001). $\mathrm{Na}^{+} / \mathrm{H}^{+}$exchange inhibition reduces hypertrophy and heart failure after myocardial infarction in rats. Am. J. Physiol. Heart Circ. Physiol. 280, H738-H745.

Lagadic-Gossmann, D., Buckler, K. J., and Vaughan-Jones, R. D. (1992). Role of bicarbonate in $\mathrm{pH}$ recovery from intracellular acidosis in the guinea-pig ventricular myocyte. J. Physiol. 458, 361-384.

Lebeche, D., Kaprielian, R., and Hajjar, R. (2006). Modulation of action potential duration on myocyte hypertrophic pathways. J. Mol. Cell. Cardiol. 40, 725-735. doi: 10.1016/j.yjmcc.2006.01.018

Lemarie, C. A., Paradis, P., and Schiffrin, E. L. (2008). New insights on signaling cascades induced by cross-talk between angiotensin II and aldosterone. J. Mol. Med. 86, 673-678. doi: 10.1007/s00109-008-0323-5

Le Prigent, K., Lagadic-Gossmann, D., Mongodin, E., and Feuvray, D. (1997). $\mathrm{HCO}_{3}^{-}$-dependent alkalinizing transporter in adult rat ventricular myocytes: characterization and modulation. Am. J. Physiol. 273, H2596-H2603.

Liu, N., Ruan, Y., Denegri, M., Bachetti, T., Li, Y., Colombi, B., et al. (2011). Calmodulin kinase II inhibition prevents arrhythmias in RyR2(R4496C+/-) mice with catecholaminergic polymorphic ventricular tachycardia. J. Mol. Cell. Cardiol. 50, 214-222. doi: 10.1016/j.yjmcc.2010.10.001

London, B., Baker, L. C., Lee, J. S., Shusterman, V., Choi, B. R., Kubota, T., et al. (2003). Calcium-dependent arrhythmias in transgenic mice with heart failure. Am. J. Physiol. Heart Circ. Physiol. 284, H431-H441. doi: 10.1152/ajpheart. 00431.2002

Meyer, M. R., Prossnitz, E. R., and Barton, M. (2011). The G protein-coupled estrogen receptor GPER/GPR30 as a regulator of cardiovascular function. Vascul. Pharmacol. 55, 17-25. doi: 10.1016/j.vph.2011.06.003

Mihailidou, A. S., Mardini, M., and Funder, J. W. (2004). Rapid, nongenomic effects of aldosterone in the heart mediated by epsilon protein kinase C. Endocrinology 145, 773-780. doi: 10.1210/en.2003-1137

Nakamura, T. Y., Iwata, Y., Arai, Y., Komamura, K., and Wakabayashi, S. (2008). Activation of $\mathrm{Na}^{+} / \mathrm{H}^{+}$exchanger 1 is sufficient to generate $\mathrm{Ca}^{2+}$ signals that induce cardiac hypertrophy and heart failure. Circ. Res. 103, 891-899. doi: 10.1161/CIRCRESAHA.108.175141

Nuss, H. B., Kaab, S., Kass, D. A., Tomaselli, G. F., and Marban, E. (1999). Cellular basis of ventricular arrhythmias and abnormal automaticity in heart failure. Am. J. Physiol. 277, H80-H91.

Orlowski, A., Ciancio, M. C., Caldiz, C. I., De Giusti, V. C., and Aiello, E. A. (2013). Reduced sarcolemmal expression and function of the NBCe1 isoform of the $\mathrm{Na}^{+} / \mathrm{HCO}_{3}^{-}$cotransporter in hypertrophied cardiomyocytes of spontaneously hypertensive rats: role of the renin-angiotensin system. Cardiovasc. Res. doi: $10.1093 / \mathrm{cvr} / \mathrm{cvt} 255$. [Epub ahead of print]. 
Patel, V. H., Chen, J., Ramanjaneya, M., Karteris, E., Zachariades, E., Thomas, P., et al. (2010). G-protein coupled estrogen receptor 1 expression in rat and human heart: protective role during ischaemic stress. Int. J. Mol. Med. 26, 193-199. doi: 10.3892/ijmm_00000452

Perez, N. G., Alvarez, B. V., Camilion De Hurtado, M. C., and Cingolani, H. E. (1995). pHi regulation in myocardium of the spontaneously hypertensive rat. Compensated enhanced activity of the Na+-H+ exchanger. Circ. Res. 77, 1192-1200. doi: 10.1161/01.RES.77.6.1192

Perez, N. G., Villa-Abrille, M. C., Aiello, E. A., Dulce, R. A., Cingolani, H. E., and Camilion De Hurtado, M. C. (2003). A low dose of angiotensin II increases inotropism through activation of reverse $\mathrm{Na}^{+} / \mathrm{Ca}^{2+}$ exchange by endothelin release. Cardiovasc. Res. 60, 589-597. doi: 10.1016/j.cardiores.2003.09.004

Perry, C., Le, H., and Grichtchenko, I. I. (2007). ANG II and calmodulin/CaMKII regulate surface expression and functional activity of NBCel via separate means. Am. J. Physiol. Renal Physiol. 293, F68-F77. doi: 10.1152/ajprenal.00454.2006

Pitt, B., Williams, G., Remme, W., Martinez, F., Lopez-Sendon, J., Zannad, F., et al. (2001). The EPHESUS trial: eplerenone in patients with heart failure due to systolic dysfunction complicating acute myocardial infarction. Eplerenone PostAMI Heart Failure Efficacy and Survival Study. Cardiovasc. Drugs Ther. 15, 79-87. doi: 10.1023/A:1011119003788

Pitt, B., Zannad, F., Remme, W. J., Cody, R., Castaigne, A., Perez, A., et al. (1999). The effect of spironolactone on morbidity and mortality in patients with severe heart failure. Randomized Aldactone Evaluation Study Investigators. N. Engl. J. Med. 341, 709-717. doi: 10.1056/NEJM199909023411001

Qin, W., Rudolph, A. E., Bond, B. R., Rocha, R., Blomme, E. A., Goellner, J. J., et al. (2003). Transgenic model of aldosterone-driven cardiac hypertrophy and heart failure. Circ. Res. 93, 69-76. doi: 10.1161/01.RES.0000080521.15238.E5

Rautureau, Y., Paradis, P., and Schiffrin, E. L. (2011). Cross-talk between aldosterone and angiotensin signaling in vascular smooth muscle cells. Steroids 76, 834-839. doi: 10.1016/j.steroids.2011.02.015

Rivard, K., Paradis, P., Nemer, M., and Fiset, C. (2008). Cardiac-specific overexpression of the human type 1 angiotensin II receptor causes delayed repolarization. Cardiovasc. Res. 78, 53-62. doi: 10.1093/cvr/cvn020

Rizzi, N., Liu, N., Napolitano, C., Nori, A., Turcato, F., Colombi, B., et al. (2008). Unexpected structural and functional consequences of the R33Q homozygous mutation in cardiac calsequestrin: a complex arrhythmogenic cascade in a knock in mouse model. Circ. Res. 103, 298-306. doi: 10.1161/CIRCRESAHA.108.171660

Rothstein, E. C., Byron, K. L., Reed, R. E., Fliegel, L., and Lucchesi, P. A. (2002). $\mathrm{H}_{2} \mathrm{O}_{2}$-induced $\mathrm{Ca}^{2+}$ overload in NRVM involves ERK1/2 MAP kinases: role for an NHE-1-dependent pathway. Am. J. Physiol. Heart Circ. Physiol. 283, H598-H605. doi: 10.1152/ajpheart.00198.2002

Sadoshima, J., and Izumo, S. (1996). Autocrine secretion of angiotensin II mediates stretch-induced hypertrophy of cardiac myocytes in vitro. Contrib. Nephrol. 118, 214-221.

Sadoshima, J., Xu, Y., Slayter, H. S., and Izumo, S. (1993). Autocrine release of angiotensin II mediates stretch-induced hypertrophy of cardiac myocytes in vitro. Cell 75, 977-984. doi: 10.1016/0092-8674(93)90541-W

Salas, M. A., Vila-Petroff, M. G., Palomeque, J., Aiello, E. A., and Mattiazzi, A. (2001). Positive inotropic and negative lusitropic effect of angiotensin II: intracellular mechanisms and second messengers. J. Mol. Cell. Cardiol. 33, 1957-1971. doi: 10.1006/jmcc.2001.1460

Sedej, S., Heinzel, F. R., Walther, S., Dybkova, N., Wakula, P., Groborz, J., et al. (2010). $\mathrm{Na}^{+}$-dependent SR Ca ${ }^{2+}$ overload induces arrhythmogenic events in mouse cardiomyocytes with a human CPVT mutation. Cardiovasc. Res. 87, 50-59. doi: 10.1093/cvr/cvq007

Shyu, K. G., Chen, C. C., Wang, B. W., and Kuan, P. (2001). Angiotensin II receptor antagonist blocks the expression of connexin 43 induced by cyclical mechanical stretch in cultured neonatal rat cardiac myocytes. J. Mol. Cell. Cardiol. 33, 691-698. doi: 10.1006/jmcc.2000.1333

Silvestre, J. S., Heymes, C., Oubenaissa, A., Robert, V., Aupetit-Faisant, B., Carayon, A., et al. (1999). Activation of cardiac aldosterone production in rat myocardial infarction: effect of angiotensin II receptor blockade and role in cardiac fibrosis. Circulation 99, 2694-2701. doi: 10.1161/01.CIR.99. 20.2694

Silvestre, J. S., Robert, V., Heymes, C., Aupetit-Faisant, B., Mouas, C., Moalic, J. M., et al. (1998). Myocardial production of aldosterone and corticosterone in the rat. Physiological regulation. J. Biol. Chem. 273, 4883-4891. doi: $10.1074 /$ jbc. 273.9 .4883
Steenbergen, C., Deleeuw, G., Rich, T., and Williamson, J. R. (1977). Effects of acidosis and ischemia on contractility and intracellular $\mathrm{pH}$ of rat heart. Circ. Res. 41, 849-858. doi: 10.1161/01.RES.41.6.849

Takeda, Y., Yoneda, T., Demura, M., Miyamori, I., and Mabuchi, H. (2000). Cardiac aldosterone production in genetically hypertensive rats. Hypertension 36, 495-500. doi: 10.1161/01.HYP.36.4.495

Varagic, J., and Frohlich, E. D. (2002). Local cardiac renin-angiotensin system: hypertension and cardiac failure. J. Mol. Cell. Cardiol. 34, 1435-1442. doi: 10.1006/jmcc.2002.2075

Vaughan-Jones, R. D., Spitzer, K. W., and Swietach, P. (2009). Intracellular $\mathrm{pH}$ regulation in heart. J. Mol. Cell. Cardiol. 46, 318-331. doi: 10.1016/j.yjmcc.2008.10.024

Vaughan-Jones, R. D., Villafuerte, F. C., Swietach, P., Yamamoto, T., Rossini, A., and Spitzer, K. W. (2006). pH-Regulated $\mathrm{Na}^{+}$influx into the mammalian ventricular myocyte: the relative role of $\mathrm{Na}^{+}-\mathrm{H}^{+}$exchange and $\mathrm{Na}^{+}-\mathrm{HCO}_{3}^{-}$Co-transport. J. Cardiovasc. Electrophysiol. 17(Suppl. 1), S134-S140. doi: 10.1111/j.1540-8167.2006.00394.x

Venetucci, L. A., Trafford, A. W., O'neill, S. C., and Eisner, D. A. (2008). The sarcoplasmic reticulum and arrhythmogenic calcium release. Cardiovasc. Res. 77, 285-292. doi: 10.1093/cvr/cvm009

Verdonck, F., Volders, P. G., Vos, M. A., and Sipido, K. R. (2003). Increased $\mathrm{Na}^{+}$concentration and altered $\mathrm{Na} / \mathrm{K}$ pump activity in hypertrophied canine ventricular cells. Cardiovasc. Res. 57, 1035-1043. doi: 10.1016/S0008-6363(02) 00734-4

Vila Petroff, M. G., Aiello, E. A., Palomeque, J., Salas, M. A., and Mattiazzi, A. (2000). Subcellular mechanisms of the positive inotropic effect of angiotensin II in cat myocardium. J. Physiol. 529(Pt 1), 189-203. doi: 10.1111/j.14697793.2000.00189.x

Villa-Abrille, M. C., Petroff, M. G., and Aiello, E. A. (2007). The electrogenic $\mathrm{Na}^{+} / \mathrm{HCO}_{3}^{-}$cotransport modulates resting membrane potential and action potential duration in cat ventricular myocytes. J. Physiol. 578, 819-829. doi: 10.1113/jphysiol.2006.120170

Wang, Y. H., Shi, C. X., Dong, F., Sheng, J. W., and Xu, Y. F. (2008). Inhibition of the rapid component of the delayed rectifier potassium current in ventricular myocytes by angiotensin II via the AT1 receptor. Br. J. Pharmacol. 154, 429-439. doi: 10.1038/bjp.2008.95

Wei, S., Guo, A., Chen, B., Kutschke, W., Xie, Y. P., Zimmerman, K., et al. (2010). T-tubule remodeling during transition from hypertrophy to heart failure. Circ. Res. 107, 520-531. doi: 10.1161/CIRCRESAHA.109. 212324

Weisser-Thomas, J., Nguyen, Q., Schuettel, M., Thomas, D., Dreiner, U., Grohe, C., et al. (2007). Age and hypertrophy related changes in contractile post-rest behavior and action potential properties in isolated rat myocytes. Age (Dordr.) 29, 205-217. doi: 10.1007/s11357-007-9040-1

Wiederkehr, M. R., Zhao, H., and Moe, O. W. (1999). Acute regulation of $\mathrm{Na} / \mathrm{H}$ exchanger NHE3 activity by protein kinase C: role of NHE3 phosphorylation. Am. J. Physiol. 276, C1205-C1217.

Xie, L. H., Chen, F., Karagueuzian, H. S., and Weiss, J. N. (2009). Oxidative-stressinduced afterdepolarizations and calmodulin kinase II signaling. Circ. Res. 104, 79-86. doi: 10.1161/CIRCRESAHA.108.183475

Yamamoto, T., Shirayama, T., Sakatani, T., Takahashi, T., Tanaka, H., Takamatsu, T., et al. (2007). Enhanced activity of ventricular $\mathrm{Na}^{+}$. $\mathrm{HCO}_{3}^{-}$cotransport in pressure overload hypertrophy. Am. J. Physiol. Heart Circ. Physiol. 293, H1254-H1264. doi: 10.1152/ajpheart.00964. 2006

Yamamoto, T., Swietach, P., Rossini, A., Loh, S. H., Vaughan-Jones, R. D., and Spitzer, K. W. (2005). Functional diversity of electrogenic $\mathrm{Na}^{+}-\mathrm{HCO}_{3}^{-}$cotransport in ventricular myocytes from rat, rabbit and guinea pig. J. Physiol. 562, 455-475. doi: 10.1113/jphysiol.2004.071068

Yoshida, K., Kim-Mitsuyama, S., Wake, R., Izumiya, Y., Izumi, Y., Yukimura, T., et al. (2005). Excess aldosterone under normal salt diet induces cardiac hypertrophy and infiltration via oxidative stress. Hypertens. Res. 28, 447-455. doi: 10.1291/hypres.28.447

Zhao, Z., Fefelova, N., Shanmugam, M., Bishara, P., Babu, G. J., and Xie, L. H. (2011). Angiotensin II induces afterdepolarizations via reactive oxygen species and calmodulin kinase II signaling. J. Mol. Cell. Cardiol. 50, 128-136. doi: 10.1016/j.yjmcc.2010.11.001

Zhou, C., Ziegler, C., Birder, L. A., Stewart, A. F., and Levitan, E. S. (2006). Angiotensin II and stretch activate NADPH oxidase to destabilize cardiac Kv4.3 
channel mRNA. Circ. Res. 98, 1040-1047. doi: 10.1161/01.RES.0000218989. 52072.e7

Zorov, D. B., Filburn, C. R., Klotz, L. O., Zweier, J. L., and Sollott, S. J. (2000). Reactive oxygen species (ROS)-induced ROS release: a new phenomenon accompanying induction of the mitochondrial permeability transition in cardiac myocytes. J. Exp. Med. 192, 1001-1014. doi: 10.1084/jem.192.7.1001

Zorov, D. B., Juhaszova, M., and Sollott, S. J. (2006). Mitochondrial ROS-induced ROS release: an update and review. Biochim. Biophys. Acta 1757, 509-517. doi: 10.1016/j.bbabio.2006.04.029

Conflict of Interest Statement: The authors declare that the research was conducted in the absence of any commercial or financial relationships that could be construed as a potential conflict of interest.
Received: 31 October 2013; paper pending published: 26 November 2013; accepted: 27 December 2013; published online: 17 January 2014.

Citation: De Giusti VC, Ciancio MC, Orlowski A and Aiello EA (2014) Modulation of the cardiac sodium/bicarbonate cotransporter by the renin angiotensin aldosterone system: pathophysiological consequences. Front. Physiol. 4:411. doi: 10.3389/fphys. 2013.00411

This article was submitted to Membrane Physiology and Membrane Biophysics, a section of the journal Frontiers in Physiology.

Copyright (0) 2014 De Giusti, Ciancio, Orlowski and Aiello. This is an open-access article distributed under the terms of the Creative Commons Attribution License (CC BY). The use, distribution or reproduction in other forums is permitted, provided the original author(s) or licensor are credited and that the original publication in this journal is cited, in accordance with accepted academic practice. No use, distribution or reproduction is permitted which does not comply with these terms. 